\begin{tabular}{|l|l|}
\hline Mff 01997,20 & Page 1 of 1 \\
\hline
\end{tabular}

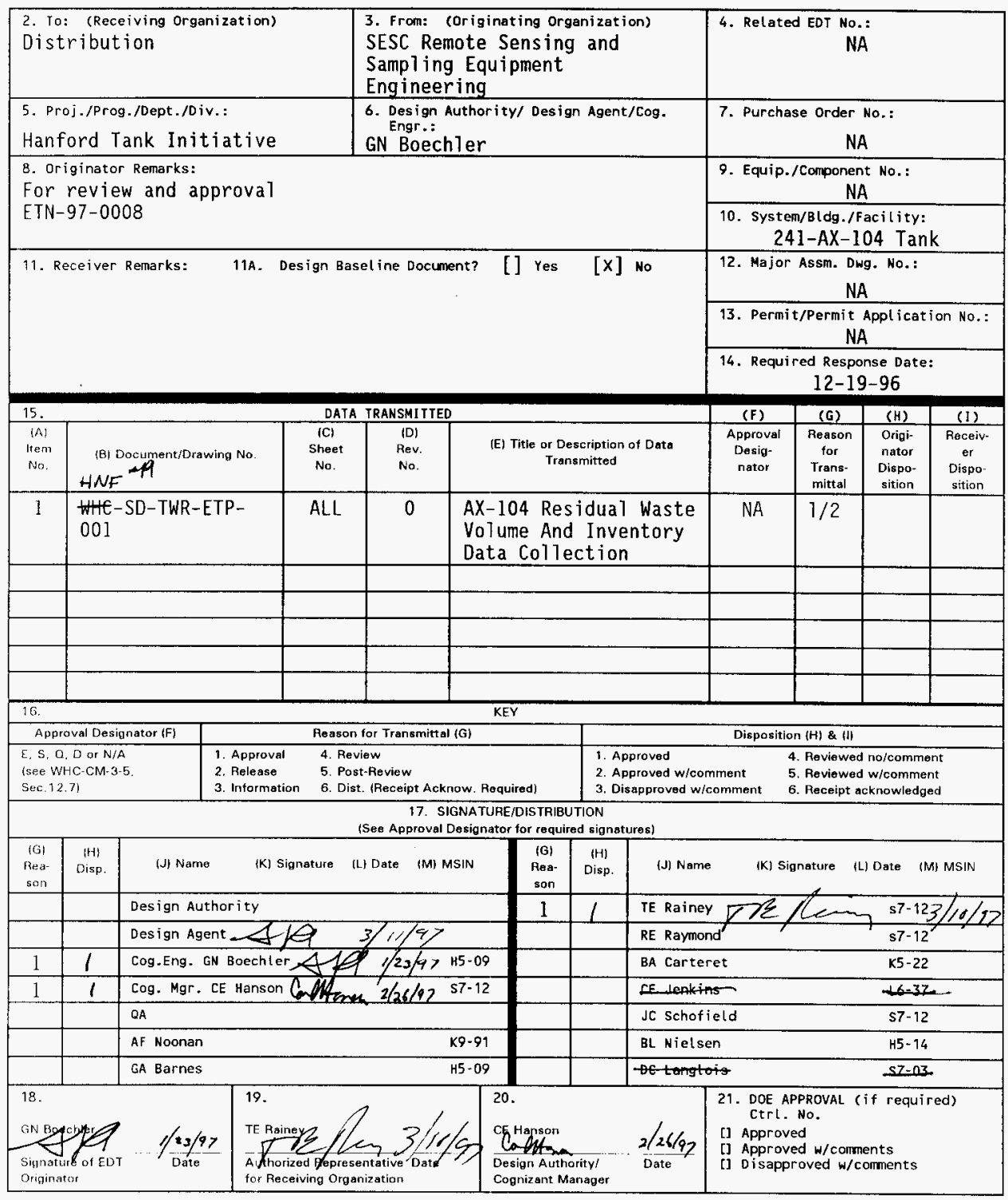

BD-7400-172-2 (05/96) GEF097 


\title{
ENGINEERING TASK PLAN FOR AX-104 RESIDUAL WASTE VOLUME AND INVENTORY DATA COLLECTION
}

\section{GN BOECHLER}

SESC, Richland, WA 99352

U.S. Department of Energy Contract DE-AC06-87RL10930

\author{
EDT/ECN: $619906 \quad$ UC: 2070 \\ Org Code: 08E00 Charge Code: E20133 \\ B\&R Code: 130074 - Total Pages: 43 \\ EW 3130070 \\ Key Words: AX-104, HANFORD TANK INITIATIVE
}

Abstract: The purpose of this Engineering Task Plan is to document the strategy, equipment and responsibilities of the tasks required to preform the volume and inventory data collection of tank $A X-104$. The project is a part of the Hanford Tanks Initiative Plan document number WHC-SD-WM-PMP-022 Revision D.

TRADEMARK DISCLAIMER. Reference herein to any specific comercial product, process, or service by trade name, trademark, manufacturer, or otherwise, does not necessarily constitute or imply its endorsement, recommendation, or favoring by the United States Government or any agency thereof or its contractors or subcontractors.

Printed in the United States of America. To obtain copies of this document contact: HHC/BCS Document Control Services, P.O. Box 1970, Mailstop H6-08, Richland WA 99352, Phone (509) 372-2420; Fax (509) 376-4989.
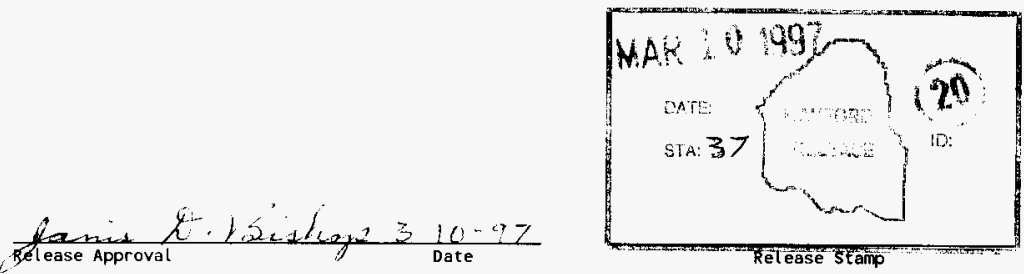


\section{ENGNEERING TASK PLAN}

FOR

AX-104 RESIDUAL WASTE VOLUME AND INVENTORY

DATA COLLECTION

Engineering Task Plan No: HNF-SD-TWR-ETP-001

Rev. 0

MAR 6, 1997 
HNF-SD-TWR-ETP-001

Rev. 0

Page 2 of 42

\section{TABLE OF CONTENTS}

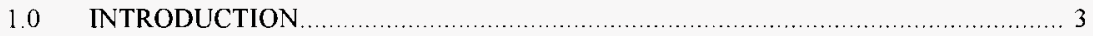

2.0 SCOPE

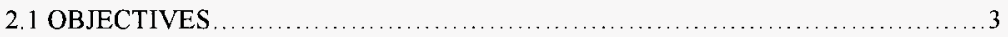

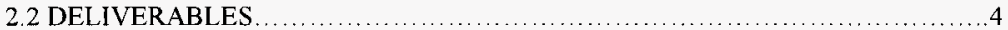

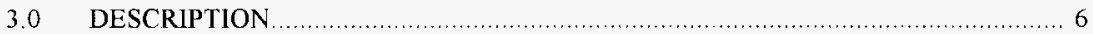

3.1 FUNCTIONAL DESCRIPTION OF EQUIPMENT . . . . . . . . . . . . . . . . . . 6

3.2 ENGINEERING TASK PLAN ...................................... 11

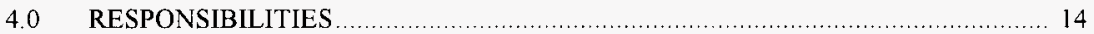

5.0 SAFETY, ENVIRONMENTAL, AND QUALITY ASSURANCE .................... 21

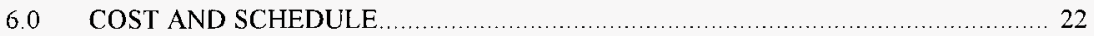

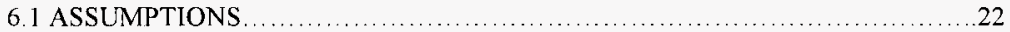

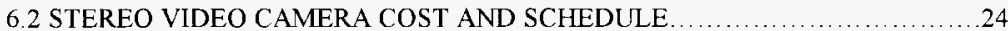

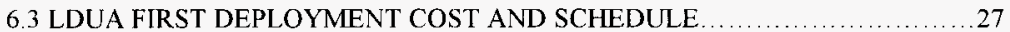

6.4 LDUA SECOND DEPLOYMENT COST AND SCHEDULE $\ldots \ldots \ldots \ldots \ldots \ldots \ldots \ldots$

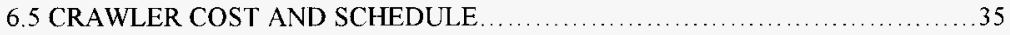

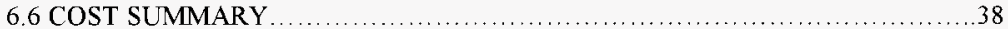

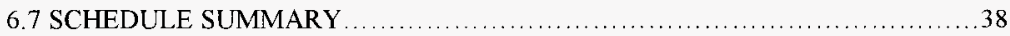

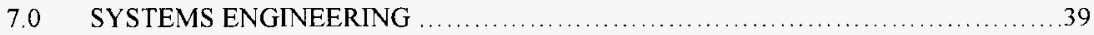

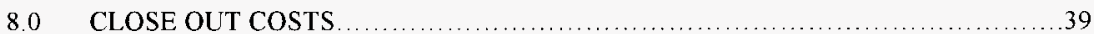

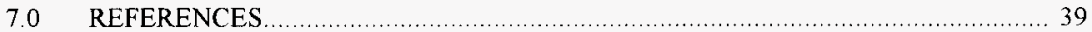


HNF-SD-TWR-ETP-001

Rev. 0

Page 3 of 42

\subsection{INTRODUCTION}

The Hanford Tank Initiate (HTI) is a four-year teaming project combining the technical and financial objectives of the U.S. Department of Energy Office of Waste Management (EM-30) and the Office of Science and Technology Development (EM-50). The HTI will provide a basis for design and regulatory decisions affecting the remainder of the tank waste retrieval program. The HTI project objective in this Engineering Task Plan is to conduct residual waste characterization activities sufficient to support retrieval and closure decisions at Tank 241-AX-104.

\section{$2.0 \quad$ SCOPE}

The scope of the HTI for 241-AX-104 is to establish retrieval performance criteria for closure, characterize residual waste, assess compliance with retrieval performance criteria, and determine readiness for closure.

\subsection{OBJECTIVES}

The objective of this ETP is to support the HTI effort by obtaining the needed volumetric, physical, radiological and chemical information on the residual waste in 241-AX-104. The following is a list of general tasks that will be required to meet the ETP objectives.

- $\quad$ Establish a functions and requirements (F\&R) document that clearly states the requirements of the equipment to be utilized in the tank. The document will use the product from the technical basis document as a basis for all its general criteria. The document will specify what will be required from the data retrieval equipment with respect to data objectives, design requirements and operation.

- Manage the efforts for design, procurement, fabrication and testing of the tools and equipment for the required waste measurements. This task includes assuring the most effective and practical equipment alternatives are pursued and verification that the acquired equipment meets the requirements the $F \& R$ document has established. The goal of the equipment acquisition strategy, will be to include a fifty percent or better involvement of the private industry for products and /or services outside 
HNF-SD-TWR-ETP-001

Rev. 0

Page 4 of 42

SESC. The acquisition strategy shall also consider involvement of the national laboratories, and EM-50 technology development programs.

- Facilitate the transfer of the equipment and technology to field operations. This effort includes establishing adequate training procedures and programs that will assure that TWRS personal can safely operate the equipment.

- Initiate the required safety and readiness documentation needed to install the equipment. This task shall include the strategy plan and schedule for initiating the required documents currently needed for in-tank work. SESC shall also be responsible for assisting with tracking this documentation. However, since these documents will be generated by others, SESC shall not be responsible for guaranteeing these documents will be delivered within the initial schedule.

\subsection{DELIVERABLES}

The following DOCUMENTS shall be delivered to the customer, Numatec Hanford Corporation (NHC):

- This Engineering Task Plan that includes visual volume assessments, LDUA deployments and crawler development tasks.

- $\quad$ Safety equipment lists for new equipment as needed

- Functions and Requirements Document that includes visual volume assessment, LDUA deployments and crawler development requirements.

- Procurement specifications for the newly purchased equipment.

- A System Design Description of the final operating equipment as needed

- Acceptance Test Procedures and Reports for all new equipment as needed 
HNF-SD-TWR-ETP-00]

Rev. 0

Page 5 of 42

- Operational Test Procedures and Reports for new equipment as needed

- As-Built drawings for all new equipment. These drawings will not necessarily be in $\mathrm{H}-2$ format (i e vendor drawings).

- Operating procedures for all new equipment

- Provide interface to operations integrated schedule on weekly basis

- A running schedule that tracks all activities on a weekly basis.

- Biweekly progress reports

- Volume estimate reports

- A final report upon completion of all activities that will include equipment performance evaluation vs F\&R specifications, data obtained vs data objectives and a final volume estimate

The following EQUIPMENT shall be supplied to the customer.

- One Crawler which meets the requirements of the Functions and Requirements document HNF-SD-WM-FRD-005.

- Tools to assist with the LDUA that meet the requirements of the Functions and Requirements document HNF-SD-WM-FRD-005.

- One fully functional LDUA. Fully functional is defined as what is needed to meet the Functions and Requirements document HNF-SD-WM-FRD005 .

- One stereo camera system or other topographical mapping system and associated equipment that meets the requirements of the Functions and Requirements document HNF-SD-WM-FRD-005 
HNF-SD-TWR-ETP-001

Rev. 0

Page 6 of 42

The following TASKS shall be performed:

- Visual assessment of waste on tank bottom, walls and internal equipment. Temperature, depth and gross gamma measurements under opened risers.

- $\quad$ First deployment of the LDUA (Phase I) - Take detailed video footage of the accessible equipment and waste in the tank and possibly taking an initial physical waste assessment.

- Second deployment of the LDUA (Phase II) - Take isotope readings of all equipment and tank waste in the immediate area accessible by the LDUA with a gamma probe. Obtain waste samples from the immediate area accessible by the LDUA. The Phase II deployment shall also utilize a calibrated probe to take physical measurements of the waste as specified.

- Install a crawler which will take isotope readings, depth measurements and take samples from specified navigable locations in the tank.

\subsection{DESCRIPTION}

Descriptions of the equipment described below are intended to be general and give the reader a feel for what will be used. The governing requirements document for the equipment which will be regularly updated as the equipment develops will be HNF-SD-WM-FRD-005. If a discrepancy in descriptions occurs between this task plan and HNF-SD-WM-FDR-005, then HNF-SD-WM-FDR-005 will take precedence.

\subsection{FUNCTIONAL DESCRIPTION OF EQUIPMENT}

\section{VISUAL VOLUME ASSESSMENT}

The visual volume assessment task utilizes a stereo-video camera and laser-ruler system to topographically map and measure dimension of waste on the tank bottom, walls and internal equipment. Photogrammetry techniques will then be 
applied to convert this information into waste volume estimates. Additional probes to measure waste temperature, height and gross-gamma will be used at the entry riser(s).

- The laser-camera system shall be relatively temperature $(<110 \mathrm{~F})$ and radiation tolerant $(<200 \mathrm{R} / \mathrm{hr}$ gamma $)$ and/or easily maintained and position insensitive

- The temperature sensor shall be able to measure the temperature from any vertical position down to the waste surface

- The gamma detector shall measure the gross gamma count from any vertical position down to the waste surface

- The depth measurement device shall measure the waste depth under the entry riser in one place minimum

\section{PHASE 1 LDUA}

The phase I LDUA deployment task will deploy a stereo video camera and possibly a waste scraper tool. The Video camera will be used to obtain close up video tape footage of as much of the tank hardware and waste as possible.

\section{PHASE II LDUA}

The phase II LDUA deployment task will deploy a calibrated probe, a gamma spectrometer probe and a sampler in the tank. The calibrated probe will be used to measure physical parameters of the tank and waste (ie. tank bottom and waste compressive strength). The gamma probe will be used to measure the ratio of gamma emitting isotopes of the waste located on the tank bottom and other intank hardware (Air Lift Circulators [ALC]). The sampler will be used to obtain waste samples from the tank bottom, ALCs, walls, dome and other in-tank hardware.

\section{LDUA Calibrated Probe:}


HNF-SD-TWR-ETP-001

Rev. 0

Page 8 of 42

- The calibrated probe system shall measure the force exerted by the probe on the waste.

- The calibrated probe system shall incorporate a calibrated color camera system.

- The calibrated probe shall have a ruler on it that can measure waste depth or depth of penetration to within $1 / 8^{\prime \prime}$

- The calibrated probe shall not penetrate the bottom of the tank liner.

- The calibrated probe shall measure the tank bottom (ie conductivity probe)

- The design of the calibrated probe shall maximize the access zone of the LDUA.

- The design of the calibrated probe shall maximize the force capabilities of the LDUA (100 lbf downward).

Simple sampler system requirements for LDUA:

- The simple sampler system shall be capable of sampling hard and soft materials (not liquids).

- The simple sampler system shall obtain at least a 10 gram sample.

- The simple sampler system shall interface with the existing $125 \mathrm{ml}$ grab sample bottles and transport mechanism.

- The simple sampler system shall not damage the tank bottom liner.

- The simple sampler system for the LDUA shall utilize the same riser as LDUA for removal.

- The simple sampler system shall obtain 1 composite sample for the accessible length of ALC. 
HNF-SD-TWR-ETP-001

Rev, 0

Page 9 of 42

LDUA phase 2 Gamma probe requirements:

- The maximum outer diameter of the gamma probe shall be $31 / 2^{\prime \prime}$

- The gamma probe cable shall be capable of supporting the gamma probe.

- The gamma probe shall not contact the waste.

- The gamma probe shall be 6" to $12^{\prime \prime}$ for the waste surface during scans.

- The gamma probe spot size shall be 12 ".

\section{CRAWLER SYSTEM}

The crawler will be equipped with a camera, depth measurement tool, sampler, gamma probe and a laser surveying system.

Crawler:

- Crawler shall end up "right-side-up" at the tank bottom when being installed.

- The crawler shall be capable of deploying the camera, depth measuring tool, gamma probe and sampling device.

- The crawler shall fit through a 34 " nominal riser.

- The crawler shall be retrievable and capable of being disposed of at the end of the mission.

- The crawler shall be operational in hard and soft waste from 4 to 6 inches deep.

Crawler camera requirements

- The camera shall be capable of viewing the crawlers relative position and 
HNF-SD-TWR-ETP-001

Rev. 0

Page 10 of 42

activities

Crawler magnitrometer depth tool requirements:

- The depth measurement tool shall measure the depth of waste from 0 to 10 inches $\pm 1 / 4$ inch.

Crawler sampler system requirements:

- The sampler system shall be capable of sampling hard and soft materials (not liquids).

- The sampler system shall obtain at least a 10 gram sample.

- The sampler system shall not damage the tank bottom liner.

Crawler Gamma probe requirements:

- The maximum outer diameter of the gamma probe shall be $31 / 2$ "

- The gamma probe shall not contact the waste.

- The gamma probe shall be 6" to $12^{\prime \prime}$ for the waste surface during scans.

- The gamma probe spot size shall be $12^{\prime \prime}$.

- The gamma probe shall not utilize count times greater than 30 minutes

Crawler Laser Surveying System

- The laser leveling system shall determine the depth of waste from 0 to 24 inches \pm 1 inch. 
HNF-SD-TWR-ETP-001

Rev. 0

Page 11 of 42

- The laser leveling system shall determine the position of the crawler in the tank.

\subsection{ENGINEERING TASK PLAN}

The following section illustrates and describes the task logic necessary to meet the project objectives. 
HNF-SD-TWR-ETP-001

Rev. 0

Page 12 of 42

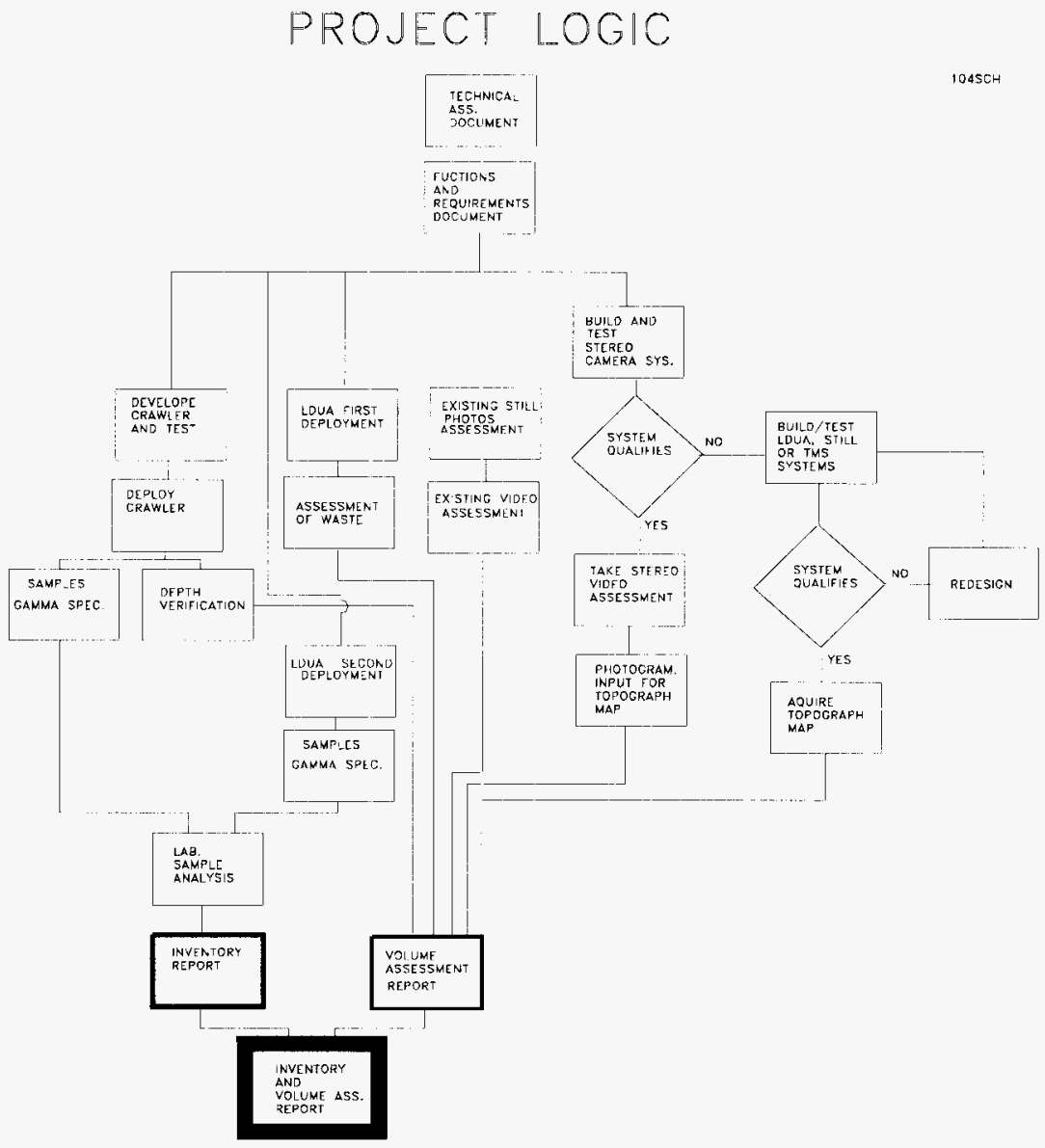


HNF-SD-TWR-ETP-001

Rev. 0

Page 13 of 42

\section{STEREO VIDEO CAMERA DEPLOYMENT LOGIC}

The main thrust of this task will be to develop a topographical map of the waste surface to assist in the volume assessment.

- A stereo video camera with laser-ruler will be developed and tested to verify it's accuracy at the FMEF facility or equivalent.

- If the system proves accurate, it will be installed in the tank to topographically map the waste using photogrammetry techniques.

- If the stereo-video camera/laser-ruler system proves inadequate alternate systems will be investigated such as a LDUA mounted system, a Topographical Mapping System (TMS), or automated machine Language/CAD systems.

- Depth, temperature and gross gamma probes will also be installed to get basic waste physical information that will assist with the design requirements of the crawler and LDUA.

\section{LDUA PHASE I DEPLOYMENT LOGIC}

The main thrust of this task will be to take detailed video footage of the accessible equipment and waste in the tank which will be used for the volume assessment.

- The first items to be completed for the Phase I LDUA deployment are the resolution of technical issues associated with the LDUA. The technical issues mostly deal with the completion of work that was not completed on the system prior to it's deployment into Tank T-106. A few of the tasks that will be performed are qualification testing to allow the LDUA to be deployed in flammable gas tanks and repair and modification to LDUA support equipment.

- The next items to be completed will be procedure updates, work package preparation, training and USQ documentation 
HNF-SD-TWR-ETP-001

Rev. 0

Page 14 of 42

- $\quad$ LMHC plans to verify readiness through the use of a readiness checklist for both the phase I and phase II deployments instead of an Operational Readiness Review (ORR).

- After approval of the facility manager the LDUA Phase I deployment will occur.

\section{LDUA PHASE 2 DEPLOYMENT LOGIC:}

The main thrust of this task will be to acquire waste samples and gamma spectral readings that will be used in the inventory report.

- For the Phase II tasks, the design and development of a calibrated probe, sampler and gamma probe will take place first. These three tasks will take place in parallel

- The next items to be completed will be procedure updates, work package preparation, training and USQ documentation. A readiness checklist is planned for the LDUA Phase II activities.

- After successful completion of the development of the Phase II equipment and documentation, the LDUA Phase Il deployment will occur

\section{CRAWLER DEPLOYMENT LOGIC}

The main thrust of this task will be to acquire samples for laboratory analysis, take gamma spectral readings to assess waste homogeneity and to take depth measurements to validate the volume assessment.

- $\quad$ The initial effort will be to evaluate potential crawlers, gamma spectrometers, depth measuring tools and cameras to be used on the system.

- It is anticipated the sampler design to be the critical design path. Therefor, a demonstration evaluation will be initiated with all potential contractors on 
HNF-SD-TWR-ETP-001

Rev. 0

Page 15 of 42

a simulated waste test bed. In parallel a independent design effort to design a sampler will be initiated. If the vendor design is sufficient the independent design will be dropped. If the vendor design doesn't meet specifications the independent design will be pursued.

- Contracts will then be let for the crawler, sampler, depth measurement tool, camera and gamma spectrometer. It will be the goal to place as few contracts for equipment development as possible. A minimum of two design reviews will be held, a preliminary and a final, where the NHC will sign off as the customer.

- A contract will also be pursued to initiate the crawler vendor to operate the equipment. If this is not possible, a shared operational contract will be pursued to involve the contractor as much as possible.

- When the equipment specifications are finalized a USQ evaluation will be initiated as well as NEPA documentation and initial operating procedures. Since the equipment will have the design requirements of WHC-SD-WMJCO-007 specified, a safety assessment is not anticipated as being necessary. However, a preliminary safety assessment (SA) will be started in parallel to the USQ. If the SA results indicate the equipment JCO safety requirements could be reduced, and time permits, a formal SA will be initiated and the design requirements modified.

- Upon successful completion of the Acceptance/Operational Test Procedures and operator training, the ORR will be performed. A Acceptance For Beneficial Use will then turn over the equipment to operations.

\subsection{RESPONSIBILITIES}

\section{Numatec Hanford Corporation shall be responsible for the following:}

TOM RAINEY

MANAGEMENT 
HNF-SD-TWR-ETP-00]

Rev. 0

Page 16 of 42

- $\quad$ NHC shall be responsible for monitoring SESC's tasks and directing SESC of any scope modifications that would effect the cost or schedule before over-runs occur

- Initiating any scope changes

- Justifying the methods being used to characterize the waste

- Justifying the volume assessment methods being used

\section{CHUCK JENKINS/ MIKE SUMSION}

VIDEO ASSESSMENT DEPLOYMENT

- Biweekly progress reports

- Weekly schedule reporting

- $\quad$ Preliminary safety equipment list

- Writing the OTP/OTR for the camera system

- Coordination of design, testing and procurement efforts

- Coordination of training and procedures required for deployment

- Coordinate the equipment fabrication and qualification testing of the stereo video camera system

- Coordinating the efforts to deploy stereo video camera/laser-ruler system

- Coordinating the efforts to take the video imaging and FDNW's photogrammetry effort to acquire a final topographical map

- Maintain stereo video camera and volume assessment project files

- Prepare waste volume assessment reports

- Develop and maintain waste volume assessment project information center including equipment, data and files. 
HNF-SD-TWR-ETP-001

Rev. 0

Page 17 of 42

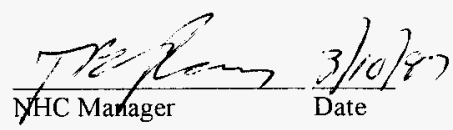

\section{Flour-Daniel Northwest shall be responsible for the following}

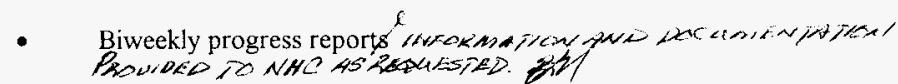

- Calibrate the video camera to maximize the accuracy of Photogrammetry work.

- $\quad$ Proof of technique tests will be conducted at the test area at FMEF to demonstrate applicability of the photogrammetry and engineering

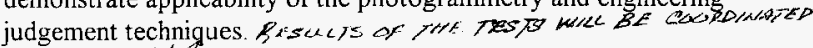
with was. Lit?

- Phase one of the tests consisted of using one $x-y$ position with only the elevation(z) axis changed. The light source remained constant, i.e. one vertical position. The second phase planned for involves the use of two horizontal positions and two vertical positions with varied lighting positions. The deliverables of the testing are the volume estimates for piles constructed within the test bed. Speed and accuracy of the volume estimates will determine feasibility of the technical approach.

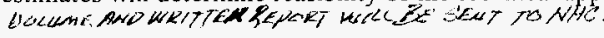

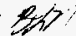

- Using engineering judgement and known equipment dimensions of the test bed, perform a volume assessment for waste piles shown in the videotape of the second phase test bed.

- $\quad$ Prepare a letter report conveying results of Phase 1 and Phase 2 tests.

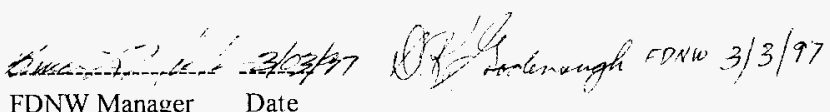

FDNW Manager Date

SESC shall be responsible for the following:

GEOFF BARNES

Phase I LDUA deployment:

- Biweekly progress reporting 
HNF-SD-TWR-ETP-001

Rev. 0

Page 18 of 42

- Responsible for the Functions and Requirements document

- Weekly schedule reporting

- Functions and requirements document which includes all equipment involved in this task plan. (ie. video camera, crawler etc.)

- Acceptance test reports

- Coordinating training and procedures for deployment

- Initiating and assuring the responsible organization completes all necessary documentation to install the equipment into the tank (USQ, training procedures, readiness checklist, work packages, etc.)

GEOFF BARNES

LDUA SECOND DEPLOYMENT

Phase II LDUA Deployment:

- Biweekly progress reporting

- Weekly schedule reporting

- Preliminary and final safety equipment list

- Acceptance test reports

- Initiating and directing efforts to develop new equipment to be used by the LDUA (ex. sampler, calibrated probe, etc)

- Generating procurement specifications for needed equipment

- Coordinating training and procedures for deployment

- Write the OTP/OTR for all the LDUA equipment

- Initiating and assuring the responsible organization completes all necessary documentation to install the equipment into the tank (USQ, training procedures, readiness checklist, work packages etc.) 
HNF-SD-TWR-ETP-001

Rev. 0

Page 19 of 42

- Maintain responsibility for the LDUA equipment until the final ABU has been issued

\section{NICK BOECHLER}

CRAWLER DEVELOPMENT

- Biweekly progress reporting

- Weekly schedule reporting

- Task Plan for all equipment included in this task plan.

- $\quad$ Acceptance test reporting

- Preliminary and final safety equipment list

- Initiating and supervising crawler equipment evaluation studies

- Initiating and monitoring sampler development activities

- Generating procurement specifications for the equipment

- Coordinating all procurement activities

- Delivering one crawler system that utilizes a camera, depth measurement device, gamma spectrometer and a sampling tool

- Coordinating the integration of the equipment into the final working system.

- Initiating and assuring the responsible organizations complete all necessary documentation to install the equipment into the tank (USQ, training procedures, NEPA documentation, ORR etc.)

- Writing the OTP/OTR for the crawler

- Maintain crawler project file 
HNF-SD-TWR-ETP-001

Rev. 0

Page 20 of 42

- Maintain responsibility for the crawler equipment until a ABU has been issued

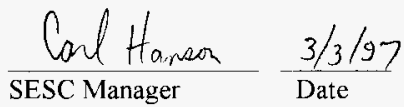

Numatec Hanford Corporation Characterization Field Engineering shall be responsible for the following activities on the LDUA, CRAWLER and STEREO CAMERA:

- Writing Operating procedures

- $\quad$ Provide cog./engineer cog. manager support

- $\quad$ Assisting in all training activities

- Directing preparations of the work packages

- Take the over-all engineering responsibility for the equipment after the final $\mathrm{ABU}$ 's have been approved and issued

- $\quad$ Provide all signature responsibilities per Table 1

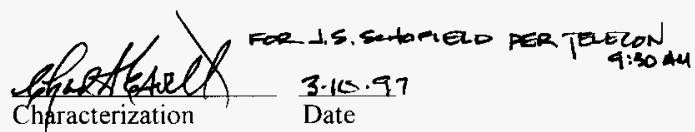

Field Engineering

Manager (NHC)

PNNL-LDUA Program Office shall be responsible for the following activities:

- Resolve all open items from the partial ABU (WHC-SD-WM-ABU-020)

- $\quad$ Perform LDUA flammable gas qualification tests 
HNF-SD-TWR-ETP-001

Rev. 0

Page 21 of 42

- $\quad$ Prepare the "World Model" of Tank AX-104

- $\quad$ Provide LDUA hardware and software training for operators and cognizant Engineers

- Modify LDUA Cold Test Cell to Mock-up AX-104 internal congestion

- Provide support to SESC and LMHC as required for readiness checklists, USQ and safety documentation, site preparation and field deployment support.

- Design, develop and test a bottom scraper tool per the functions and requirements identified in WHC-SD-WM-FRD-005.

- $\quad$ Procure gripper

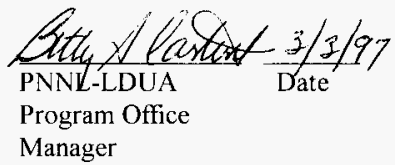

Lockheed Martin Hanford Corporation (LMHC) shall be responsible for the following activities:

- $\quad$ Procurement and testing the stereo laser camera system

- Overview camera work for LDUA

- Operating the stereo camera system in the tank

- $\quad$ Prepare field work packages and obtain signatures as needed on all equipment (stereo camera, LDUA and crawler).

- Determine adequacy of equipment for deployment

- $\quad$ Direct the LDUA deployment operations which will not interfere with characterization milestones or commitments

- Direct the Crawler system deployment which will not interfere with 
HNF-SD-TWR-ETP-001

Rev, 0

Page 22 of 42

characterization milestones or commitments

- Taking responsibility for the all equipment after a Acceptance For

Beneficial Use has been issued for the equipment

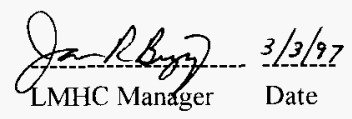


HNF-SD-TWR-ETP-001

Rev. 0

Page 23 of 42

Table 1: Signature Approvals for Cognizant Engineer and Cognizant Manager

\begin{tabular}{|c|c|c|c|c|}
\hline Document & SESC & $\mathrm{NHC}$ & $\begin{array}{l}\text { Design } \\
\text { Authority }\end{array}$ & $\begin{array}{l}\text { Char. Field } \\
\text { Engineering }\end{array}$ \\
\hline Finginecring Task $\mathrm{P}$ & $c$ & $s$ & - & s \\
\hline Functions And kequirements & $c$ & $s$ & - & . \\
\hline Performance Specitication & ? & s & - & * \\
\hline Preliminary Design & c & - & - & * \\
\hline Final Design & c: & $s$ & $\mathrm{~s}$ & . \\
\hline Procurement & $\because$ & & - & \\
\hline System Design Description & $\because$ & s & $\mathbf{s}$ & * \\
\hline Acceptance Test and Acceptarce Test Report & $\because$ & $s$ & - & * \\
\hline Oparating and mairtenance procedures & - & s & - & c \\
\hline Safety Assessment & $\mathrm{c}$ & * & $\mathrm{s}$ & * \\
\hline Ciperational Test & - & $c$ & - & * \\
\hline Acceptance for Beneficial Lse & $\cdot$ & $s$ & - & $c$ \\
\hline SEL - preliminary & C & s & - & * \\
\hline SLLL - tinal & $s$ & $\cdot$ & $\mathbf{s}$ & c \\
\hline Readiness Review & $\cdot$ & s & $\mathbf{s}$ & $c$ \\
\hline Work Packigres & - & - & $\mathbf{S}$ & c \\
\hline
\end{tabular}

C: Cognizant Engineer and Cognizant Manager Signature

$\mathrm{S}$ : This organization will co-sign with the cognizant organization.

*: Co-signing Organization in the event SESC or cognizant manager does not have all the required training.

\subsection{SAFETY, ENVIRONMENTAL AND QUALITY ASSURANCE}

Signature requirements other than what is in called out in the above table will be determined by safety class per WHC-CM-4-46, Section 9.0, "Safety Classification of Structures, Systems, and Components" and CM-3-5, section 12.7, "Approval of Environmental, Safety, and Quality Affecting Documents" 


\subsection{COST AND SCHEDULE}

Since the cost and schedules are dependant on many variables, they are not considered "fixed price or fixed schedules". However, it will be NHC's responsibility to control these costs and schedules with input form SESC.

\subsection{ASSUMPTIONS}

A list of the major assumptions for the successful development and deployment of the respective equipment are listed below. The basic assumptions that funding is not cut and management can place the required priorities with operations so scheduling is not a problem, are assumed for each deployment.

\section{STEREO CAMERA}

- Layoffs don't effect deployment activities

- No Operational Readiness Review (ORR) or Readiness Assessment (RA) will be required

- $\quad$ No Safety Assessment (SA) will be required

- $\quad$ No Safety Equipment List (SEL) will be required

- Stereo camera /laser ruler qualification testing is successful

- $\quad$ Lasers are approved by Flammable Gas Board (FGB)

\section{LDUA PHASE 1}

- $\quad$ No ORR or RA will be required

- No SA will be required

- No SEL will be required

- $\quad$ No DOE reviewes will be required

- $\quad$ FGB approves the design as meeting JCO control set 2 requirements 
- Equipment will fit or can be made to fit on the tank without extensive modifications

\section{LDUA PHASE 2}

- $\quad \mathrm{JCO}$ is approved and does not change the existing requirements

- A reliable sampler can be built

- The Technical Basis document does not change the assumed number of samples to be taken

- The temperature in the tank is low enough for the proper operation of the gamma spectrometer

- $\quad$ No DOE reviews will be required

\section{CRAWLER}

- Slucers are removable and disposable to make 34 inch riser available

- Bidders respond favorably to specification technical, cost and schedule requirements

- Successful bidder can design and build the equipment to meet the JCO control set 2 requirements.

- A reliable sampler can be built

- The Technical Basis document does not change the assumed number of samples to be taken

- The temperature in the tank is low enough for the proper operation of the gamma spectrometer

- The gamma levels and temperature in the tank are low enough for the operation of the crawler camera system 
HNF-SD-TWR-ETP-001

Rev. 0

Page 26 of 42

6.2

STEREO VIDEO CAMERA COST AND SCHEDULE 


\begin{tabular}{|c|c|c|c|c|c|c|c|c|}
\hline \multirow[b]{2}{*}{ ID } & \multirow[b]{2}{*}{ Task Name } & \multirow[b]{2}{*}{ Early Start } & \multirow[b]{2}{*}{ Early Finish } & \multirow[b]{2}{*}{ Cost } & \multicolumn{3}{|r|}{1997} & \\
\hline & & & & & Qtr 4 & Qtr 1 & \begin{tabular}{l|l} 
Qtr 2 & Qtr:
\end{tabular} & $\bar{r}$ \\
\hline 1 & Visual Volume Ass. & Tue $10 / 1 / 96$ & Thu $7 / 3 / 97$ & $\$ 246,750.00$ & & & & \\
\hline 2 & Revision A & Tue 10/1/96 & Thu 10/31/96 & $\$ 11,960.00$ & & & & \\
\hline 3 & Project Planning & Fri $11 / 1 / 96$ & Fri $11 / 22 / 96$ & $\$ 8,320,00$ & & & & \\
\hline 4 & Design Stereo Video Sys & Mon 10/14/96 & Fri 11/29/96 & $\$ 4,550.00$ & & & & \\
\hline 5 & Fab. System & Mon $12 / 2 / 96$ & Fri 12/27/96 & $\$ 27,200.00$ & & & & \\
\hline 6 & Qualify System & Mon 12/30/96 & Fri $1 / 24 / 97$ & $\$ 31,200.00$ & & & & \\
\hline 7 & Qualify Software & Mon 1/27/97 & Fi 2/14/97 & $\$ 10,200.00$ & & & & \\
\hline 8 & DECISION POINT & Fri $1 / 24 / 97$ & Fri $1 / 24 / 97$ & $\$ 0.00$ & & & & \\
\hline 9 & Write Test Procedures & Mon $1 / 13 / 97$ & The $1 / 30 / 97$ & $\$ 7,280.00$ & & & & \\
\hline 10 & Training & Fri $1 / 31 / 97$ & Wed $2 / 19 / 97$ & $\$ 10,920.00$ & & & & \\
\hline 11 & Test System & Mon $2 / 17 / 97$ & Fri $2 / 28 / 97$ & $\$ 26,000,00$ & & & & \\
\hline 12 & USQ Evaluation & Mon 1/20/97 & Thu $2 / 6 / 97$ & $\$ 3,640.00$ & & & & \\
\hline 13 & Work Package & Mon 3/3/97 & Tue $3 / 11 / 97$ & $\$ 10,920.00$ & & & & \\
\hline 14 & Approvals & Wed $3 / 12 / 97$ & Thu 3/20/97 & $\$ 3,640,00$ & & & & \\
\hline 15 & Deploy To Field & Fri $3 / 21 / 97$ & Thu $4 / 10 / 97$ & $\$ 59,720.00$ & & & & LM[5] \\
\hline 16 & Interpret Data & Fri 4/11/97 & Thu $5 / 22 / 97$ & $\$ 15,600.00$ & & & $\mathbf{C}$ & \\
\hline 17 & Write Report & Fri 5/23/97 & Thu $7 / 3 / 97$ & $\$ 15,600.00$ & & & NHC & \\
\hline 18 & & & & & & & & \\
\hline 19 & Slucer removal & Mon 3/24/97 & Fri $5 / 23 / 97$ & $\$ 126,600.00$ & & & & \\
\hline 20 & Slucer inspection packag & Mon $3 / 24 / 97$ & Fri $3 / 28 / 97$ & $\$ 2,600,00$ & & & & \\
\hline 21 & Inspect slucer pit & Mon 3/31/97 & Fri $4 / 11 / 97$ & $\$ 26,000,00$ & & & & \\
\hline 22 & USQ & Mon 4/14/97 & Fri $4 / 25 / 97$ & $\$ 5,200.00$ & & & & \\
\hline 23 & Slucer removal package & Mon $4 / 28 / 97$ & Fri 5/9/97 & $\$ 5,200.00$ & & & & \\
\hline 24 & Remove slucer & Mon 5/12/97 & Fri $5 / 23 / 97$ & $\$ 87,600,00$ & & & & $\mathrm{C}$ \\
\hline
\end{tabular}


HNF-SD-TWR-ETP-001

Rev. 0

Budget Report as of Tue 3/4/97

VOLUME ASSESSMENT

Page 28 of 42

\begin{tabular}{clrrr} 
ID & Task Name & Fixed Cost & Total Cost & Baseline \\
\hline 24 & Remove slucer & $\$ 0.00$ & $\$ 87,600.00$ & $\$ 87,600.00$ \\
15 & Deploy To Fleld & $\$ 0.00$ & $\$ 59,720.00$ & $\$ 10,320.00$ \\
6 & Qualify System & $\$ 0.00$ & $\$ 31,200.00$ & $\$ 3 t, 200,00$ \\
5 & Fab. System & $\$ 0.00$ & $\$ 27,200.00$ & $\$ 13,600.00$ \\
11 & Test System & $\$ 0.00$ & $\$ 26,000.00$ & $\$ 26,000.00$ \\
21 & Inspect slucer pit & $\$ 0.00$ & $\$ 26,000.00$ & $\$ 26,000.00$ \\
16 & Interpret Data & $\$ 0.00$ & $\$ 15,600.00$ & $\$ 15,600.00$ \\
17 & Write Report & $\$ 0.00$ & $\$ 15,600.00$ & $\$ 15,600.00$ \\
2 & Revision A & $\$ 0.00$ & $\$ 11,960.00$ & $\$ 11,960.00$ \\
10 & Training & $\$ 0.00$ & $\$ 10,920.00$ & $\$ 10,920.00$ \\
13 & Work Package & $\$ 0.00$ & $\$ 10,920.00$ & $\$ 10,920.00$ \\
7 & Qualify Software & $\$ 0.00$ & $\$ 10,200.00$ & $\$ 10,200.00$ \\
3 & Project Planning & $\$ 0.00$ & $\$ 8,320.00$ & $\$ 8,320.00$ \\
9 & Write Test Procedures & $\$ 0.00$ & $\$ 7,280.00$ & $\$ 7,280.00$ \\
22 & USQ & $\$ 0.00$ & $\$ 5,200.00$ & $\$ 5,200.00$ \\
23 & Slucer removal package & $\$ 0.00$ & $\$ 5,200.00$ & $\$ 5,200,00$ \\
4 & Design Stereo Video Sys. & $\$ 0.00$ & $\$ 4,550.00$ & $\$ 4,550.00$ \\
12 & USQ Evaluation & $\$ 0.00$ & $\$ 3,640.00$ & $\$ 3,640.00$ \\
14 & Approvals & $\$ 0.00$ & $\$ 3,540.00$ & $\$ 3,640.00$ \\
20 & Slucer inspection package & $\$ 0.00$ & $\$ 2,600.00$ & $\$ 2,600.00$ \\
8 & DECISION POINT & $\$ 0.00$ & $\$ 0.00$ & $\$ 0.00$ \\
18 & & & & $\$ 310,350.00$
\end{tabular}


HNF-SD-TWR-ETP-001

Rev. 0

Page 29 of 42

6.3

LDUA FIRST DEPLOYMENT COST AND SCHEDULE 
HNF-SD-TWR-ETP-001

Rev. 0

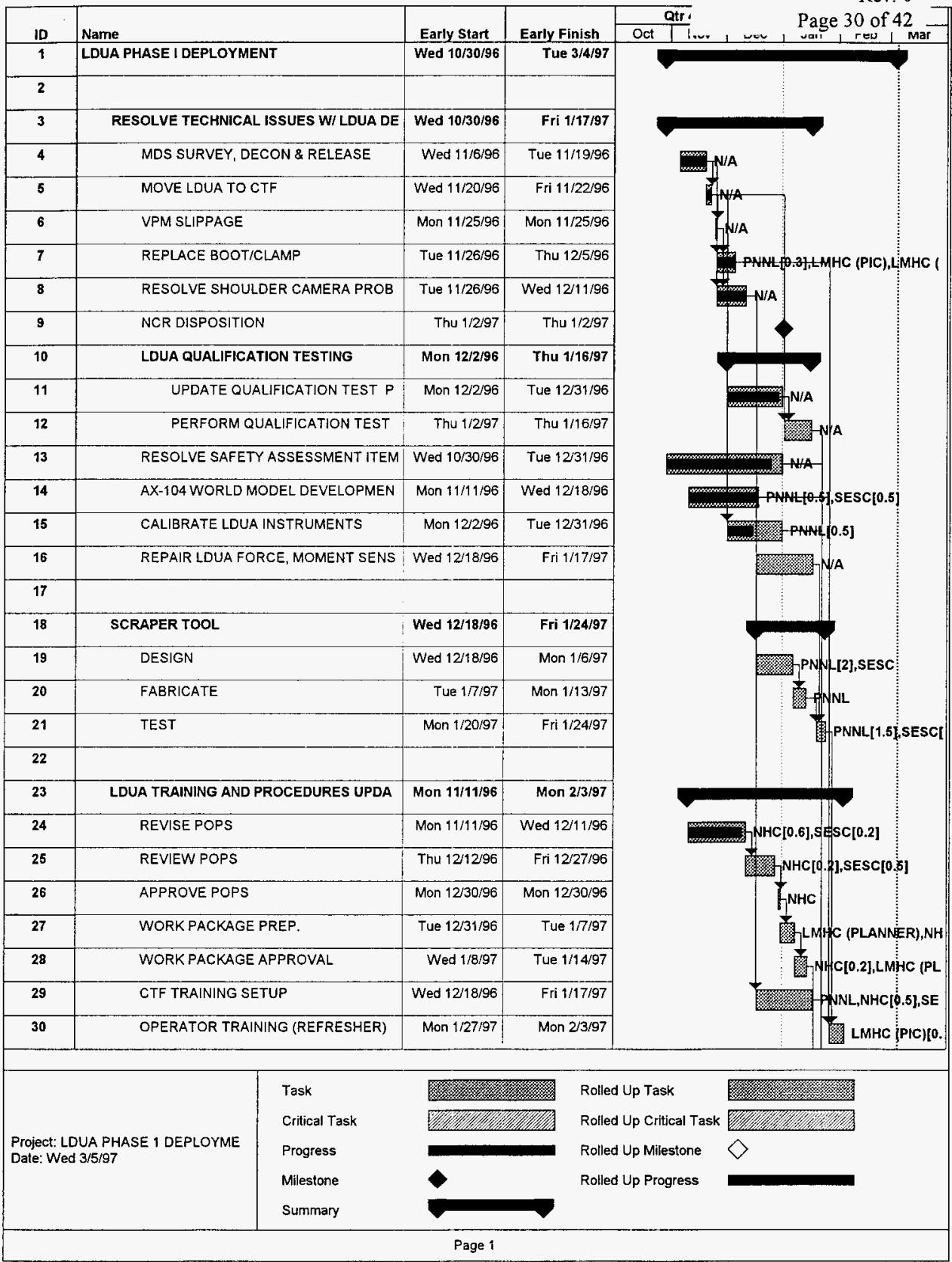




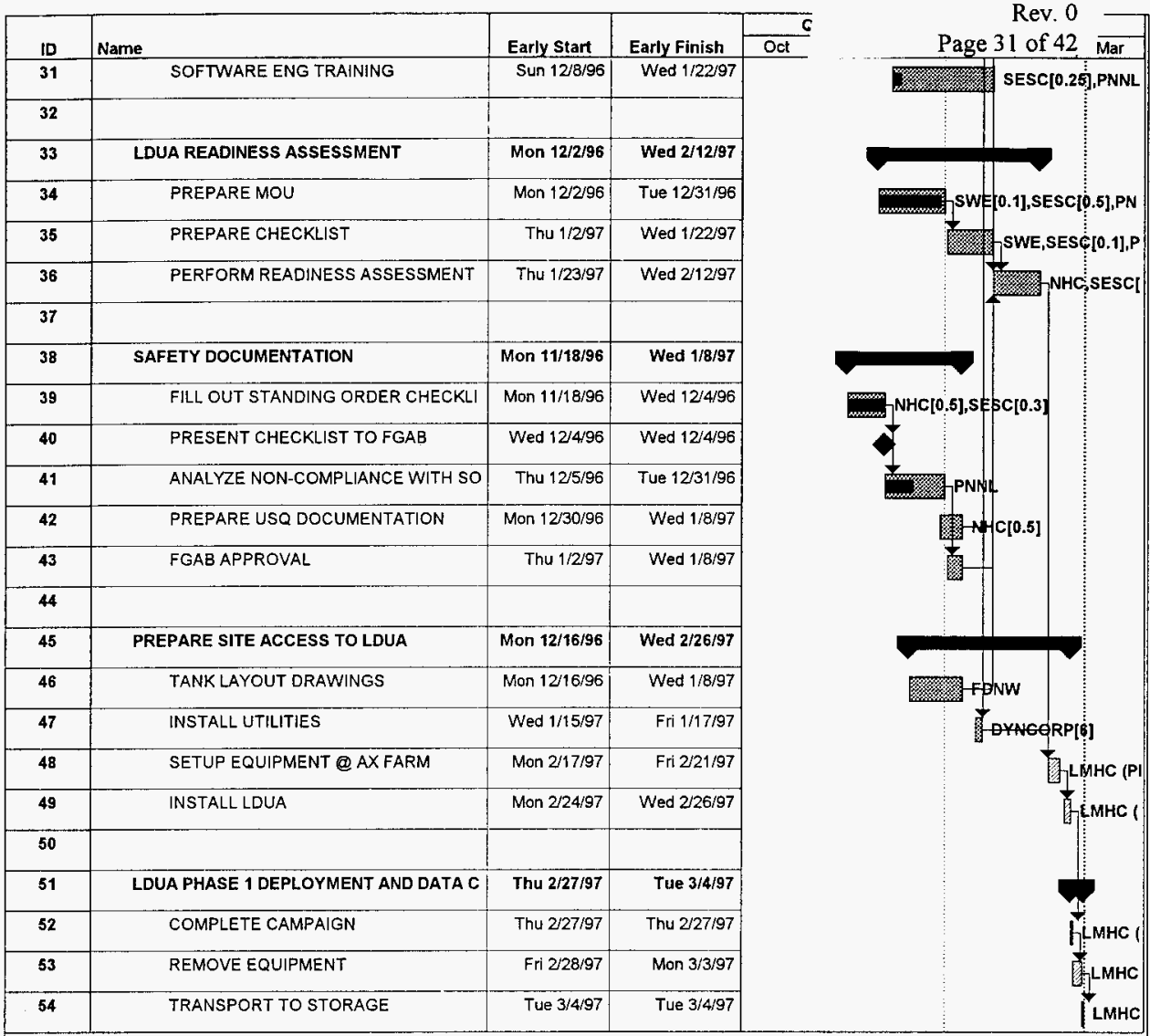

Project: LDUA PHASE 1 DEPLOYME Date: Wed 3/5/97
Task

Critical Task

Progress

Milestone

Summary

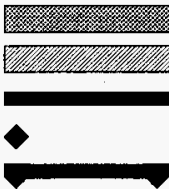

Rolled Up Task

Rolled Up Critical Task

Rolled Up Milestone

Rolled Up Progress

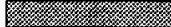

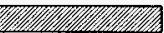

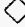




\begin{tabular}{|c|c|c|c|c|}
\hline ID & Task Name & Fixed Cost & Total Cost & Baseline \\
\hline 48 & SETUP EQUIPMENT @ AX FARM & $\$ 0.00$ & $\$ 30,800,00$ & $\$ 30,800.00$ \\
\hline 19 & DESIGN & $\$ 0.00$ & $\$ 19,254,40$ & $\$ 19,254.40$ \\
\hline 29 & CTF TRAINING SETUP & $\$ 0.00$ & $\$ 19,120.00$ & $\$ 19,120.00$ \\
\hline 49 & INSTALL LDUA & $\$ 0.00$ & $\$ 18,480.00$ & $\$ 18,480.00$ \\
\hline 14 & AX-104 WORLD MODEL DEVELOP & $\$ 0.00$ & $\$ 17,400.00$ & $\$ 17,400.00$ \\
\hline 41 & ANALYZE NON-COMPLIANCE WIT & $\$ 0.00$ & $\$ 14,416.00$ & $\$ 14,416.00$ \\
\hline 35 & PREPARE CHECKLIST & $\$ 0.00$ & $\$ 12,888.00$ & $\$ 12,888.00$ \\
\hline 31 & SOFTWARE ENG TRAINING & $\$ 0.00$ & $\$ 10,440.00$ & $\$ 10,440.00$ \\
\hline 36 & PERFORM READINESS ASSESSME & $\$ 0.00$ & $\$ 9,888.00$ & $\$ 9,888.00$ \\
\hline 47 & INSTALL UTILITIES & $\$ 0.00$ & $\$ 9,360.00$ & $\$ 9,360.00$ \\
\hline 30 & OPERATOR TRAINING (REFRESHE & $\$ 4,598.40$ & $\$ 9,196.80$ & $\$ 9,196.80$ \\
\hline 15 & CALIBRATE LDUA INSTRUMENTS & $\$ 0.00$ & $\$ 8,480.00$ & $\$ 8,480.00$ \\
\hline 7 & REPLACE BOOT/CLAMP & $\$ 0.00$ & $\$ 8,248.00$ & $\$ 8,248.00$ \\
\hline 46 & TANK LAYOUT DRAWINGS & $\$ 0.00$ & $\$ 7,800,00$ & $\$ 2,600.00$ \\
\hline 21 & TEST & $\$ 0.00$ & $\$ 7,720.00$ & $\$ 7.720 .00$ \\
\hline 53 & REMOVE EQUIPMENT & $\$ 0.00$ & $\$ 7,332.00$ & $\$ 7,332.00$ \\
\hline 24 & REVISE POPS & $\$ 0.00$ & $\$ 7,328.00$ & $\$ 7,328.00$ \\
\hline 52 & COMPLETE CAMPAIGN & $\$ 0.00$ & $\$ 5,888.00$ & $\$ 5,888.00$ \\
\hline 20 & FABRICATE & $\$ 0.00$ & $\$ 4,240.00$ & $\$ 4,240,00$ \\
\hline 34 & PREPARE MOU & $\$ 0.00$ & $\$ 4,224.00$ & $\$ 4,224.00$ \\
\hline 25 & REVIEW POPS & $\$ 0.00$ & $\$ 3,760.00$ & $\$ 3,760.00$ \\
\hline 27 & WORK PACKAGE PREP. & $\$ 0.00$ & $\$ 3,664,00$ & $\$ 3,664.00$ \\
\hline 39 & FILL OUT STANDING ORDER CHE & $\$ 0.00$ & $\$ 3,416.00$ & $\$ 3,416.00$ \\
\hline 28 & WORK PACKAGE APPROVAL & $\$ 0.00$ & $\$ 1,820.00$ & $\$ 1,820.00$ \\
\hline 42 & PREPARE USQ DOCUMENTATION & $\$ 0.00$ & $\$ 1,820.00$ & $\$ 2,600.00$ \\
\hline 54 & TRANSPORT TO STORAGE & $\$ 0.00$ & $\$ 1,616.00$ & $\$ 1,616.00$ \\
\hline 26 & APPROVE POPS & $\$ 0.00$ & $\$ 520.00$ & $\$ 520.00$ \\
\hline 4 & MDS SURVEY, DECON \& RELEASE & $\$ 0.00$ & $\$ 0.00$ & $\$ 0.00$ \\
\hline 5 & MOVE LDUA TO CTF & $\$ 0.00$ & $\$ 0,00$ & $\$ 0.00$ \\
\hline 6 & VPM SLIPPAGE & $\$ 0,00$ & $\$ 0.00$ & $\$ 0.00$ \\
\hline 8 & RESOLVE SHOULDER CAMERA PR & $\$ 0.00$ & $\$ 0.00$ & $\$ 0.00$ \\
\hline 9 & NCR DISPOSITION & $\$ 0.00$ & $\$ 0,00$ & $\$ 0.00$ \\
\hline 11 & UPDATE QUALIFICATION TEST PR & $\$ 0.00$ & $\$ 0.00$ & $\$ 0.00$ \\
\hline 12 & PERFORM QUALIFICATION TEST & $\$ 0.00$ & $\$ 0.00$ & $\$ 0.00$ \\
\hline 13 & RESOLVE SAFETY ASSESSMENT I & $\$ 0.00$ & $\$ 0.00$ & $\$ 0.00$ \\
\hline 16 & REPAIR LDUA FORCE, MOMENT S & $\$ 0.00$ & $\$ 0.00$ & $\$ 0.00$ \\
\hline 40 & PRESENT CHECKLISTT TO FGAB & $\$ 0.00$ & $\$ 0.00$ & $\$ 0.00$ \\
\hline 43 & FGAB APPROVAL & $\$ 0.00$ & $\$ 0.00$ & $\$ 0.00$ \\
\hline
\end{tabular}


HNF-SD-TWR-ETP-00I

Rev. 0

Page 33 of 42

6.4

LDUA SECOND DEPLOYMENT

COST AND SCHEDULE 
HNF-SD-TWR-ETP-001

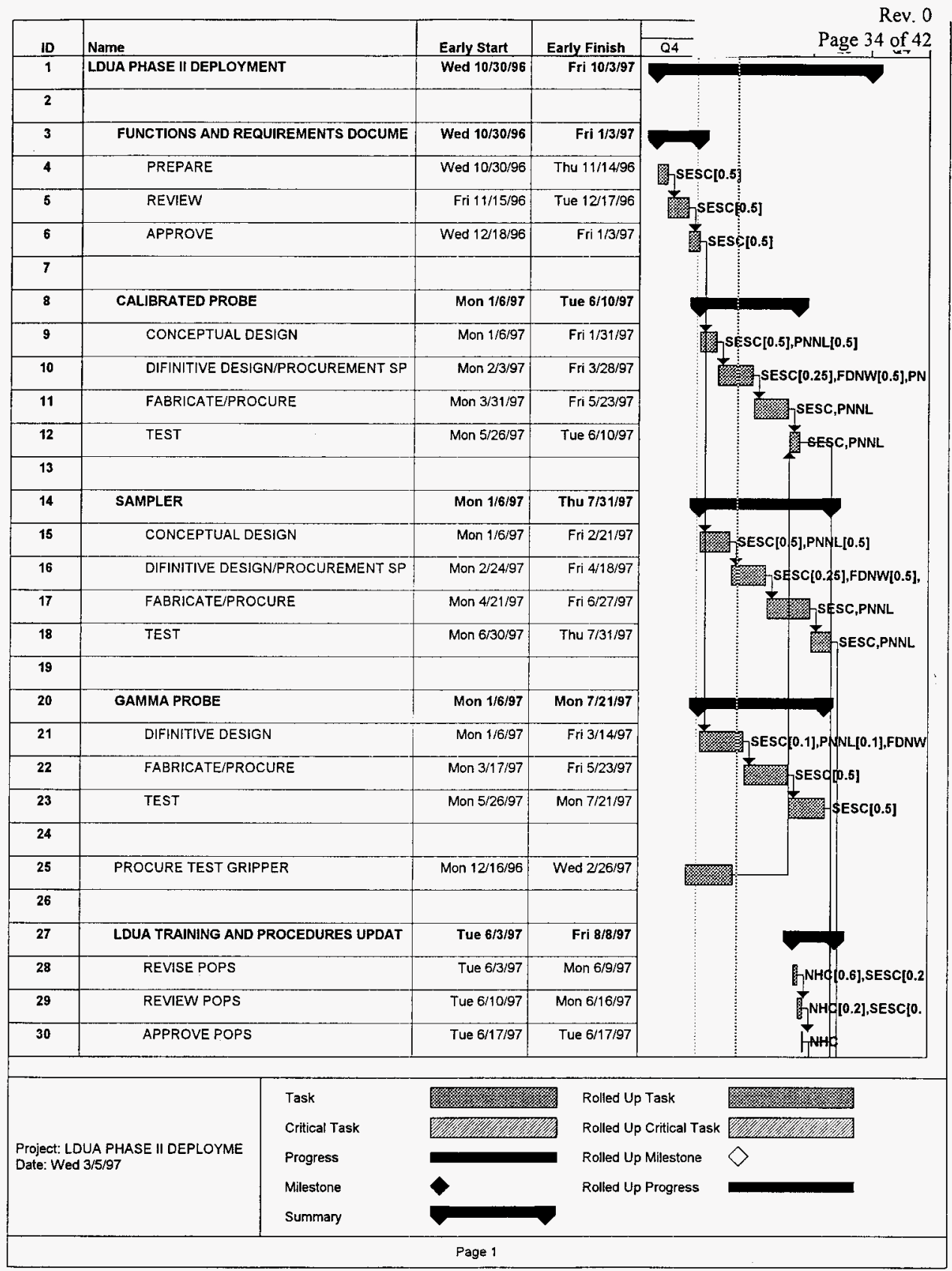


HNF-SD-TWR-ETP-001

Rev. 0

\begin{tabular}{|c|c|c|c|c|c|c|}
\hline ID & Name & Early Start & Early Finish & Q4 & $\overline{1}$ & \\
\hline 31 & WORKPACKAGE PREP. & Wed 6/18/97 & Tue $6 / 24 / 97$ & & & \\
\hline 32 & WORKPACKAGE APPROVAL & Wed 6/25/97 & Tue $7 / 1 / 97$ & & & \\
\hline 33 & OPERATOR TRAINING (REFRESHER) & Fri $8 / 1 / 97$ & Fri $8 / 8 / 97$ & & & \\
\hline \multicolumn{7}{|l|}{34} \\
\hline 35 & SAFETY DOCUMENTATION & Tue $7 / 1 / 97$ & Wed $8 / 13 / 97$ & & & \\
\hline 36 & FILL OUT STANDING ORDER CHECKLIS & Tue $7 / 1 / 97$ & Mon $7 / 14 / 97$ & & & \\
\hline 37 & PREPARE USQ DOCUMENTATION & Tue $7 / 15 / 97$ & Mon $7 / 28 / 97$ & & & \\
\hline 38 & PRESENT CHECKLIST TO FGAB & Mon 7/28/97 & Mon $7 / 28 / 97$ & & & \\
\hline 39 & ANALYZE NON COMPLIANCE WITH SOC & Tue $7 / 15 / 97$ & Wed $8 / 6 / 97$ & & & \\
\hline 40 & FGAB APPROVAL & Thu $8 / 7 / 97$ & Wed $8 / 13 / 97$ & & & \\
\hline \multicolumn{7}{|l|}{41} \\
\hline 42 & PREPARE SITE ACCESS TO LDUA & Mon 8/11/97 & Wed $8 / 20 / 97$ & & & \\
\hline 43 & SETUP EQUIPMENT @ AX FARM & Mon $8 / 11 / 97$ & Fri $8 / 15 / 97$ & & & \\
\hline 44 & INSTALL LDUA & Mon $8 / 18 / 97$ & Wed $8 / 20 / 97$ & & & GMHC (PIC) \\
\hline \multicolumn{7}{|l|}{45} \\
\hline 46 & LDUA PHASE II DEPLOYMENT & Tue 9/30/97 & Fri 10/3/97 & & & \\
\hline 47 & COMPLETE CAMPAIGN & Tue 9/30/97 & Tue $9 / 30 / 97$ & & & \\
\hline 48 & REMOVE EQUIPMENT & Wed $10 / 1 / 97$ & Thu $10 / 2 / 97$ & & & \\
\hline 49 & TRANSPORT TO STORAGE & Fri $10 / 3 / 97$ & Fri 10/3/97 & & & L.MHC ( \\
\hline
\end{tabular}

Project: LDUA PHASE II DEPLOYME Date: Wed 3/5/97
Task

Critical Task

Progress

Milestone

Summary

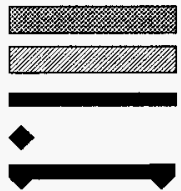

Page 2
Rolled Up Task

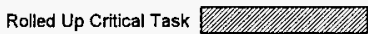

Rolled Up Milestone

Rolled Up Progress 


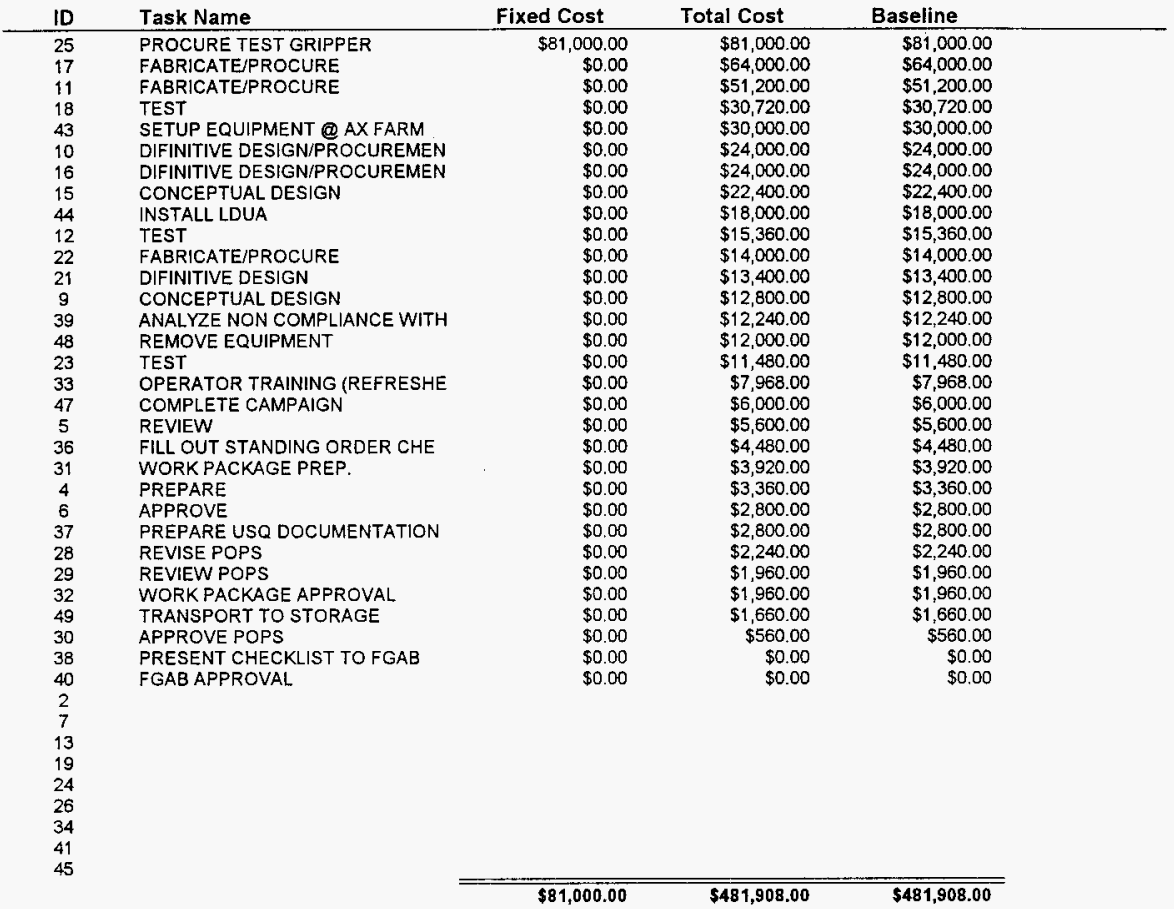


HNF-SD-TWR-ETP-001

Rev. 0

Page 37 of 42

\section{5 \\ CRAWLER COST AND SCHEDULE}




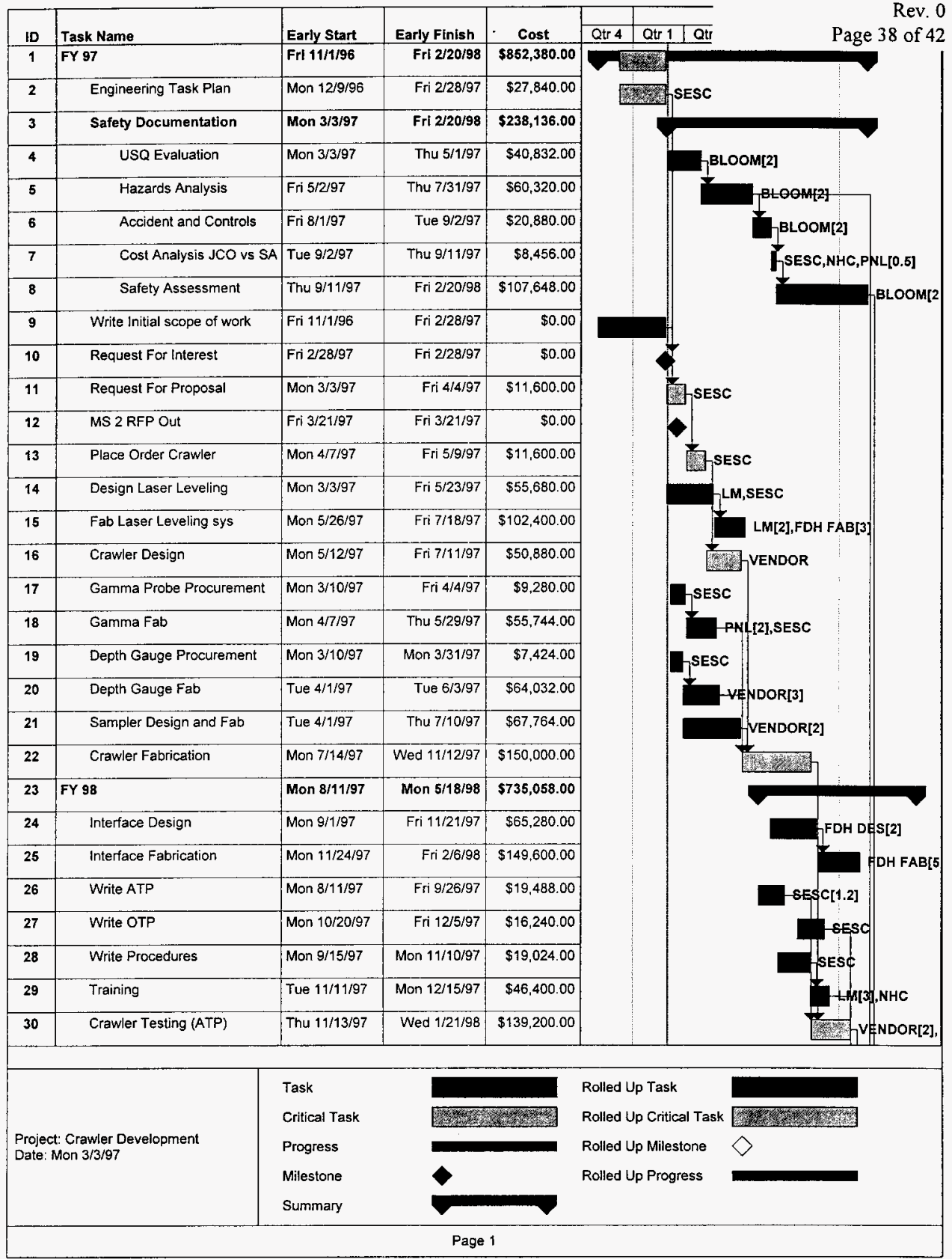


HNF-SD-TWR-ETP-001

\begin{tabular}{|c|c|c|c|c|c|c|c|c|}
\hline \multirow[b]{2}{*}{ ID } & \multirow[b]{2}{*}{ Task Name } & \multirow[b]{2}{*}{ Early Start } & \multirow[b]{2}{*}{ Eariy Finish } & \multirow[b]{2}{*}{ - Cost } & & \multicolumn{2}{|r|}{1997} & \\
\hline & & & & & Qtr 4 & Qtr 1 & Qtr 2 & \\
\hline 31 & MS 4 OTP COMPLETE & Mon 1/12/98 & Mon $1 / 12 / 98$ & $\$ 0.00$ & & & & \\
\hline 32 & Crawler Testing (OTP) & Thu $1 / 22 / 98$ & Tue $2 / 24 / 98$ & $\$ 55,680,00$ & & & & \\
\hline 33 & ORR & Wed 2/25/98 & Mon 4/6/98 & $\$ 31,552.00$ & & & & \\
\hline 34 & MS 5 DEPLOY CRAWLER & Tue $4 / 7 / 98$ & Tue $4 / 7 / 98$ & $\$ 0.00$ & & & & \\
\hline 35 & Deploy Crawler & Tue $4 / 7 / 98$ & Tue $5 / 12 / 98$ & $\$ 136,864.00$ & & & & \\
\hline 36 & Deploy Crawler (VENDOR) & Tue $4 / 7 / 98$ & Mon 5/18/98 & $\$ 55,730.00$ & & & & \\
\hline
\end{tabular}

\begin{tabular}{|l|lll|}
\hline & Task & Rolled Up Task \\
& Critical Task & & Rolled Up Critical Task \\
$\begin{array}{l}\text { Project: Crawer Development } \\
\text { Date: Mon 3/3/97 }\end{array}$ & Progress & Rolled Up Milestone \\
& Milestone & & \\
& Summary & & \\
\hline
\end{tabular}


HNF-SD-TWR-ETP-001

Budget Report as of Tue 3/4/97

Rev. 0

Crawler Development

Page 40 of 42

G. N. BOECHLER

\begin{tabular}{|c|c|c|c|c|}
\hline ID & Task Name & Early Start & Early Finish & Cost \\
\hline 22 & Crawler Fabrication & Mon $7 / 14 / 97$ & Wed $11 / 12 / 97$ & $\$ 150,000.00$ \\
\hline 25 & Interface Fabrication & Mon $11 / 24 / 97$ & Fri $2 / 6 / 98$ & $\$ 149,600,00$ \\
\hline 30 & Crawler Testing (ATP) & Thu $11 / 13 / 97$ & Wed $1 / 21 / 98$ & $\$ 139,200.00$ \\
\hline 35 & Deploy Crawler & Tue $4 / 7 / 98$ & Tue 5/12/98 & $\$ 136,864.00$ \\
\hline 8 & Safety Assessment & Thu $9 / 11 / 97$ & Fri $2 / 20 / 98$ & $\$ 107,648.00$ \\
\hline 15 & Fab Laser Leveling sys & Mon 5/26/97 & Fri $7 / 18 / 97$ & $\$ 102,400.00$ \\
\hline 21 & Sampler Design and Fab & Tue 4/1/97 & Thu $7 / 10 / 97$ & $\$ 67,764.00$ \\
\hline 24 & Interface Design & Mon 9/1/97 & Fri $11 / 21 / 97$ & $\$ 65,280.00$ \\
\hline 20 & Depth Gauge Fab & Tue $4 / 1 / 97$ & Tue 6/3/97 & $\$ 64,032.00$ \\
\hline 5 & Hazards Analysis & Fri $5 / 2 / 97$ & Thu $7 / 31 / 97$ & $\$ 60,320.00$ \\
\hline 18 & Gamma Fab & Mon 4/7/97 & Thu 5/29/97 & $\$ 55,744.00$ \\
\hline 36 & Deploy Crawler (VENDOR) & Tue $4 / 7 / 98$ & Mon 5/18/98 & $\$ 55,730,00$ \\
\hline 14 & Design Laser Leveling & Mon $3 / 3 / 97$ & Fri 5/23/97 & $\$ 55,680.00$ \\
\hline 32 & Crawler Testing (OTP) & Thu $1 / 22 / 98$ & Tue 2/24/98 & $\$ 55,680.00$ \\
\hline 16 & Crawler Design & Mon 5/12/97 & Fri $7 / 11 / 97$ & $\$ 50,880.00$ \\
\hline 29 & Training & Tue $11 / 11 / 97$ & Mon $12 / 15 / 97$ & $\$ 46,400.00$ \\
\hline 4 & USQ Evaluation & Mon $3 / 3 / 97$ & Thu $5 / 1 / 97$ & $\$ 40,832,00$ \\
\hline 33 & ORR & Wed 2/25/98 & Mon 4/6/98 & $\$ 31,552.00$ \\
\hline 2 & Engineering Task Plan & Mon $12 / 9 / 96$ & Fri $2 / 28 / 97$ & $\$ 27,840.00$ \\
\hline 6 & Accident and Controls & Fri 8/1/97 & Tue $9 / 2 / 97$ & $\$ 20,880.00$ \\
\hline 26 & Write ATP & Mon $8 / 11 / 97$ & Fri $9 / 26 / 97$ & $\$ 19,488.00$ \\
\hline 28 & Write Procedures & Mon $9 / 15 / 97$ & Mon $11 / 10 / 97$ & $\$ 19,024.00$ \\
\hline 27 & Write OTP & Mon $10 / 20 / 97$ & Fri $12 / 5 / 97$ & $\$ 16,240,00$ \\
\hline 11 & Request For Proposal & Mon 3/3/97 & Fri $4 / 4 / 97$ & $\$ 11,600,00$ \\
\hline 13 & Place Order Crawler & Mon 4/7/97 & Fri 5/9/97 & $\$ 11,600.00$ \\
\hline 17 & Gamma Probe Procurement & Mon 3/10/97 & Fri $4 / 4 / 97$ & $\$ 9,280.00$ \\
\hline 7 & Cost Analysis JCO vs SA & Tue 9/2/97 & Thu $9 / 11 / 97$ & $\$ 8,456.00$ \\
\hline 19 & Depth Gauge Procurement & Mon $3 / 10 / 97$ & Mon 3/31/97 & $\$ 7,424,00$ \\
\hline 9 & Write Initial scope of work & Fri $11 / 1 / 96$ & Fri $2 / 28 / 97$ & $\$ 0.00$ \\
\hline 10 & Request For Interest & Fri $2 / 28 / 97$ & Fri $2 / 28 / 97$ & $\$ 0.00$ \\
\hline 12 & MS 2 RFP Out & Fri 3/21/97 & Fri $3 / 21 / 97$ & $\$ 0.00$ \\
\hline 31 & MS 4 OTP COMPLETE & Mon $1 / 12 / 98$ & Mon $1 / 12 / 98$ & $\$ 0.00$ \\
\hline \multirow[t]{2}{*}{34} & MS 5 DEPLOY CRAWLER & Tue $4 / 7 / 98$ & Tue $4 / 7 / 98$ & $\$ 0.00$ \\
\hline & & & & $\overline{1,587,438.00}$ \\
\hline
\end{tabular}




\subsection{COST SUMMARY:}

\section{FY 97}

Volume Assessment: $\$ 310 \mathrm{~K}$

LDUA Phase 1: $\quad \$ 245 \mathrm{~K}$

Slucer Removal: $\quad \$ 126 \mathrm{~K}$

LDUA Phase 2: $\quad \$ 482 \mathrm{~K}$

Crawler: $\quad \$ 825 \mathrm{~K}$

NHC PNNL Mgt \$200 K

TOTAL $\$ 2,215 \mathrm{~K}$

FY 98 Crawler: $\$ 735 \mathrm{~K}$

GRAND TOTAL: $\quad \mathbf{\$ 2 , 9 5 0} \mathrm{K}$

\subsection{SCHEDULE SUMMARY:}

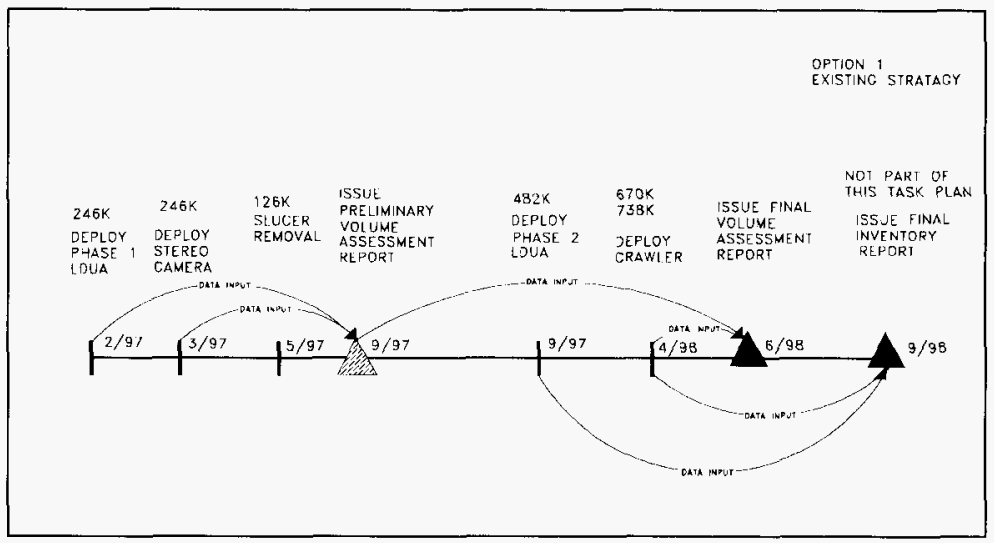


HNF-SD-TWR-ETP-001

Rev. 0

Page 42 of 42

\subsection{SYSTEMS ENGINEERING}

Systems engineering procedures and practices will be utilized throughout this project. Due to the multiple equipment deployments and varying deployment objectives the same procedures might not be utilize for each case. However, Systems Engineering Procedures WHC-IP-1117 SEP-1.0 through 11.2 will be utilized as needed as well as Configuration Management Technical Baseline procedures CCP-01-04 throughout the project.

\subsection{CLOSEOUT COSTS}

If funding gets cut or delayed on one or all of the tasks (Stereo Camera, LDUA 1 and 2, Crawler) the in progress tasks need some responsible closure. This would include contract closures, project file updating, document closures equipment storage etc. The cost and time will vary with what stage the task is in. Generally, the farther into the task, the longer it will take to close it out. Below is a estimate of these costs and times for a average close out

STEREO CAMERA Three weeks and $10 \mathrm{~K}$

LDUA 1 and $2 \quad$ Four weeks and $15 \mathrm{~K}$

CRAWLER Three weeks and $15 \mathrm{~K}$ (plus accrued costs and penalties to contractors)

\subsection{REFERENCES}

- WHC-CM-6-1, "Standard Engineering Practices"

- HNF-SD-TD-FRD-005 Rev. 0 "Functions and Requirements for AX-104 Residual Waste Volume and Inventory Data Collection

- NHF-SD-WM-TI-799 Rev. 0 "Technical Basis Document"

- WHC-CM-4-2 "Quality Assurance Program Planning"

- WHC-CM-6-1 Engineering Practices

- WHC-IP-1 17 Systems Engineering Procedures

- CCP-01-04 Technical Base line Procedures 


\section{DISTRIBUTION SHEET}

\begin{tabular}{|c|c|c|c|c|c|}
\hline \multirow{2}{*}{$\begin{array}{l}\text { To } \\
\text { Distribution }\end{array}$} & \multirow{2}{*}{\multicolumn{3}{|c|}{$\begin{array}{l}\text { From } \\
\text { Remote Sensing and Sampling } \\
\text { Equipment Engineering }\end{array}$}} & \multicolumn{2}{|l|}{ Page 1 of 1} \\
\hline & & & & \multicolumn{2}{|c|}{ Date $03 / 10 / 97$} \\
\hline \multicolumn{4}{|l|}{ Project Title/Work Order } & \multicolumn{2}{|c|}{ EDT No. 619906} \\
\hline \multicolumn{4}{|c|}{$\begin{array}{l}\text { AX-104 Residual Waste Volume and Inventory Data Collection, } \\
\text { HNF-SD-TWR-ETP-001, Rev. 0/E20133 }\end{array}$} & \multicolumn{2}{|l|}{ ECN No. $\quad$ N/A } \\
\hline Name & MSIN & $\begin{array}{c}\text { Text } \\
\text { With All } \\
\text { Attach. }\end{array}$ & Text Only & $\begin{array}{l}\text { Attach./ } \\
\text { Appendix } \\
\text { Only }\end{array}$ & $\begin{array}{l}\text { EDT/ECN } \\
\text { Only }\end{array}$ \\
\hline $\begin{array}{l}\text { G. A. Barnes } \\
\text { J. R. Biggs } \\
\text { G. N. Boechler } \\
\text { B. A. Carteret } \\
\text { D. A. Dodd } \\
\text { C. A. Esvelt } \\
\text { D. K. Goodenough } \\
\text { C. E. Hanson } \\
\text { W. J. Kennedy } \\
\text { B. L. Nielsen } \\
\text { A. F. Noonan } \\
\text { E. M. Northrup (2 copies) } \\
\text { T. E. Rainey } \\
\text { R. E. Raymond } \\
\text { F. R. Reich } \\
\text { J. C. Schofield } \\
\text { M. L. Sumsion } \\
\text { G. L. Troyer } \\
\text { Central Files }\end{array}$ & $\begin{array}{l}H 5-09 \\
S 7-03 \\
H 5-09 \\
K 5-22 \\
\text { T6-50 } \\
\text { S7-12 } \\
\text { H5-14 } \\
\text { S7-12 } \\
\text { S7-03 } \\
\text { H5-14 } \\
\text { K9-91 } \\
\text { H6-12 } \\
\text { S7-12 } \\
\text { S7-12 } \\
\text { L5-55 } \\
\text { S7-12 } \\
\text { S7-03 } \\
\text { T6-50 } \\
\text { A3-88 }\end{array}$ & $\begin{array}{l}x \\
x \\
x \\
x \\
x \\
x \\
x \\
x \\
x \\
x \\
x \\
x \\
x \\
x \\
x \\
x \\
x \\
x \\
x\end{array}$ & & & \\
\hline
\end{tabular}

